\title{
Assessment of Total Phenolic, Antioxidant, and Antibacterial Activities of Passiflora Species
}

\author{
Shiamala Devi Ramaiya, ${ }^{1}$ Japar Sidik Bujang,, and Muta Harah Zakaria ${ }^{2}$ \\ ${ }^{1}$ Department of Animal Science and Fisheries, Faculty of Agriculture and Food Sciences, \\ Universiti Putra Malaysia Bintulu Sarawak Campus, 97008 Bintulu, Sarawak, Malaysia \\ ${ }^{2}$ Department of Aquaculture, Faculty of Agriculture, Universiti Putra Malaysia (UPM), 43400 Serdang, \\ Selangor Darul Ehsan, Malaysia
}

Correspondence should be addressed to Shiamala Devi Ramaiya; shiamala_32@yahoo.com

Received 26 October 2013; Accepted 16 December 2013; Published 21 January 2014

Academic Editors: A. Geng and A. A. Guevara-Garcia

Copyright (C) 2014 Shiamala Devi Ramaiya et al. This is an open access article distributed under the Creative Commons Attribution License, which permits unrestricted use, distribution, and reproduction in any medium, provided the original work is properly cited.

\begin{abstract}
This study focused on total phenolic content (TPC) and antioxidant and antibacterial activities of the leaves and stems of Passiflora quadrangularis, P. maliformis, and P. edulis extracted using three solvents: petroleum ether, acetone, and methanol. The maximum extraction yields of antioxidant components from the leaves and stems were isolated using methanol extracts of P. edulis (24.28\%) and P. quadrangularis (9.76\%), respectively. Among the leaf extracts, the methanol extract of P. maliformis had the significantly highest TPC and the strongest antioxidant activity, whereas among the stem extracts, the methanol extract of $P$. quadrangularis showed the highest phenolic amount and possessed the strongest antioxidant activity. The antibacterial properties of the Passiflora species were tested using the disc diffusion method against 10 human pathogenic bacteria. The largest inhibition zone was observed for the methanol extract of P. maliformis against B. subtilis. Generally, extracts from the Passiflora species exhibit distinct inhibition against Gram-positive but not Gram-negative bacteria. Based on the generated biplot, three clusters of bacteria were designated according to their performance towards the tested extracts. The present study revealed that methanol extracts of the Passiflora contain constituents with significant phenolic, antioxidant, and antibacterial properties for pharmaceutical and nutraceutical uses.
\end{abstract}

\section{Introduction}

Natural products have received significant interest as source for new drug development in biomedical research. The modern pharmaceutical industry is highly dependent on plant-based medicines, with more than $50 \%$ of drug substances derived from natural resources [1]. Plants are known to produce phytochemicals, which are potential sources of anticarcinogenic, anticancer, antimicrobial, and antioxidant activity; these compounds include flavonoids, phenolic acids, and tannins $[2,3]$. Research has focused on the discovery of clinically useful antimicrobial drugs and functional food from natural resources for pharmaceutical and nutraceutical uses $[4,5]$. Additionally, the increasing interest in traditional ethnomedicine may lead to the discovery of novel therapeutic agents.
Passion fruit is an agronomically important crop and is used commercially in the fruit industry. This plant belongs to the genus Passiflora and is extensively grown in the tropical and subtropical regions of the world. Passion fruit is widely distributed over Central America and South America, with more production in the latter region [6]. Brazil is the major producer and consumer of passion fruit worldwide. In Malaysia, this fruit is cultivated on a small scale due to the prevalence of suitable growing conditions and increase in demand [7].

In recent years, researchers have shown increasing interest in the passion fruit plant due to its phytotherapeutic properties, ethnobotanical uses, chemotaxonomic information, and the interaction of the plant with its environment; these factors have been suggested as selection criteria for potential sources of natural molecules of pharmaceutical relevance [8]. 
The leaves, stems, roots, and fruits of Passiflora species have long been used in folk medicine and are finding an increasingly important place in modern medicine. Traditionally, the flower of Passiflora has been valued medicinally for its sedative, antispasmodic, anxiolytic, and hypotensive activity, as well as its sleep-inducing effects [6, 9-11]. Although a number of species, including $P$. edulis and P. quadrangularis, have been valued for the above purposes, $P$. incarnata has demonstrated the strongest effects, and its efficacy is comparable with that of other species [12-16]. The ethnobotanical literature has also indicated that the Passiflora plant contains a variety of compounds, including alkaloids, phenols, glycoside flavonoids, and cyanogenic constituents [10]. The leaf extract of Passiflora species has been shown to possess anxiolytic and sedative activity [17-19], as well as treatment for diabetes and hypertension [20], and anti-inflammatory [21], cytotoxic [22], antioxidant $[23,24]$, antibacterial [2527], and antifungal properties [28]. In support of these claims, a study by Birner and Nicolls [29] has reported the isolation of an antibacterial and antifungal compound called Passicol from P. edulis. This plant has a continuing history of use in Ayurveda and homeopathic medicine as a treatment for a number of ailments [30]. The seeds possess an antifungal protein (Passiflin) [31] and an antifungal peptide (Pe-AFP1), which protect the plant from invasion by pathogenic fungi [32].

From the above review, it may be concluded that although many studies have examined the ethnobotanical attributes and medicinal uses of purple passion fruits, little information exists on phenolic content, antioxidant capacities, and antibacterial properties of other Passiflora species. To fill this gap, the present study screens various parts of several Passiflora species for the total phenolic content and antioxidant and antibacterial activity extracted using three different solvents: petroleum ether, acetone, and methanol.

\section{Materials and Methods}

2.1. Plant Materials. Leaves and stems of P. quadrangularis, $P$. maliformis, and P. edulis were collected randomly from 10 plants of each species at the passion fruit farm at Universiti Putra Malaysia Bintulu Sarawak Campus (UPMKB), Bintulu, Sarawak. Specimen identification and botanical nomenclature were based on the scheme of Ulmer and MacDougal [6]. The plant parts were brought to the laboratory and immediately inspected, cleaned with distilled water, and dried in the shade at room temperature for 2 weeks. The dried parts were homogenized to a fine powder and stored in airtight containers until used for the analyses described below.

2.2. Preparations of Extracts. For each of the dried parts, $5 \mathrm{~g}$ of powered sample was separately extracted with $50 \mathrm{~mL}$ of three different solvents (petroleum ether, acetone, and methanol) using a shaking water bath at $80 \mathrm{rpm}$ for 48 hours at room temperature. The extracts were then centrifuged at $500 \times \mathrm{g}$ for 10 min and filtered through Whatman No. 2 filter paper. Each extract was then evaporated to dryness. The concentrated extracts were suspended in dimethyl sulfoxide (DMSO) and stored in a refrigerator at $4^{\circ} \mathrm{C}$ prior to the analyses.
2.3. Determination of Total Phenolic Content (TPC). TPC was determined using the Folin-Ciocalteu (Merck) method as described by Asami et al. [33]. The extract solution in appropriate solvent $(1 \mathrm{~mL})$ was added with $0.3 \mathrm{~mL}$ of FolinCiocalteu reagent. Six minutes later, $10 \mathrm{~mL}$ of $7 \%$ sodium carbonate solution was added, mixed well, and left it for 2 hours. The absorbance readings were taken at $740 \mathrm{~nm}$ on an 1100 Series spectrophotometer. The experiment was performed in triplicate. The quantification of TPC was conducted using a calibration curve prepared with a gallic acid standard $\left(R^{2}=\right.$ 0.997). The results were expressed as g garlic acid equivalent (GAE) per $100 \mathrm{~g} \mathrm{DW}$ of extract.

2.4. 2,2-Diphenyl-1-picrylhydrazyl (DPPH) Radical Scavenging Assay. Total antioxidant activity (TAA) of the Passiflora extracts against DPPH radicals was determined according to the modified methods of Brand-Williams et al. [34]. Three milliliter DPPH $(100 \mu \mathrm{M})$ in methanol was added to $1.0 \mathrm{~mL}$ of Passiflora extract. After $30 \mathrm{~min}$ incubation period at room temperature the absorbance was taken against blank prepared without extract at $517 \mathrm{~nm}$ on an 1100 Series spectrophotometer. The concentration of sample required to scavenge $50 \%$ $\mathrm{DPPH}\left(\mathrm{EC}_{50}\right)$ was determined by linear regression for the concentration and $\mathrm{EC}_{50}(\%)$. The experiment was performed in triplicate, and the results were expressed as $\mu \mathrm{g} / \mathrm{mL}^{-1}$. A lower $\mathrm{EC}_{50}$ value indicates a higher antioxidant activity.

2.5. Bacterial Strains. The plant extracts were individually tested against 10 human pathogenic bacteria: the 5 Grampositive bacteria Bacillus subtilis (ATCC 6633), Bacillus cereus (ATCC 11778), Listeria monocytogenes (ATCC 7644), Streptococcus gallolyticus (ATCC 49147), and Staphylococcus aureus (MTCC 554231) and the five Gram-negative bacteria Pseudomonas aeruginosa (ATCC 27853), Klebsiella oxytoca (ATCC 49131), Proteus vulgaris (ATCC 49132), Salmonella enteritidis (MTCC 125239), and Escherichia coli (MTCC 423155). The bacterial strains were obtained from Thermo Fisher Scientific. The bacterial strains were cultured overnight at $37^{\circ} \mathrm{C}$ in nutrient broth. The cultures were then maintained at $4^{\circ} \mathrm{C}$ and were subcultured prior to analysis.

2.6. Antibacterial Activity. The antibacterial activity of the Passiflora species extracts was studied by the disc diffusion method as reported by Lalitha [35]. The turbidity of each bacterial suspension was adjusted to a $0.5 \mathrm{McF}$ arland standard, with each suspension containing $1.5 \times 10^{8} \mathrm{CFU} / \mathrm{mL}$. The bacterial strains were spread individually in sterile Petri dishes on prepared nutrient agar medium. Sterilized filter paper discs (5.5 $\mathrm{mm}$ in diameter) were impregnated with $5 \mu \mathrm{L}$ of $50 \mu \mathrm{g} / \mu \mathrm{L}$ extract $(250 \mu \mathrm{g} / \mathrm{disc})$ and placed on the surface of the agar plates that had previously been inoculated with the tested bacteria. A disc impregnated with chloramphenicol $(10 \mu \mathrm{g} /$ disc) was used as a standard, while the respective solvents were used as the negative controls. The agar plates were incubated at $37^{\circ} \mathrm{C}$ for 24 hours. The antibacterial activity was examined by measuring the diameters of the growth inhibition zones $(\mathrm{mm})$ for the tested pathogenic bacteria compared to the standards. The measurement of the inhibition zones was conducted using three sample replications. 
2.7. Statistical Analysis. The statistical software SAS 9.0 was used for data analysis. Means were compared using single factor analysis of variance (ANOVA). A post hoc Tukey's test $(P<0.05)$ was performed if the ANOVA result was significant. Principal component analysis (PCA) based on the Pearson method was conducted using XLSTAT software to determine the relationship between the activity of the plant parts extracts and the pathogenic bacteria.

\section{Results and Discussion}

3.1. Extract Yields. The extract yields of the leaves and stems of $P$. quadrangularis, $P$. maliformis, and $P$. edulis obtained using the three extraction solvents are presented in Table 1. The extraction yields showed significant differences among the Passiflora species and the different solvents tested. The extract yields of the leaves and stems ranged from 3.70 to $24.28 \%$ and 1.53 to $9.76 \%$ (per $5 \mathrm{~g}$ dry weight), respectively. Methanol was the most effective extractant of antioxidant compounds, followed by acetone and petroleum ether. This trend was similar to the findings of Gahlaut and Chhillar [36]. Both methanol and ethanol have been established as effective solvents for extracting antioxidant compounds from plant materials [37]. Methanol yielded the greatest percentage of crude extract from the leaves of $P$. edulis $(24.28 \pm 0.67 \%)$, whereas lower yields were obtained from the petroleum ether extracts of $P$. edulis and $P$. maliformis, $4.39 \pm 0.46 \%$ and $3.70 \pm 0.97 \%$, respectively. For the stem, the highest percentage of crude extract was obtained from the methanol extracts of $P$. quadrangularis $(9.76 \pm 0.20 \%)$, and the lowest extract yield was recorded from the petroleum ether extracts of $P$. maliformis $(1.53 \pm 0.11 \%)$. The present study revealed that the extraction yield varied with the solvents used and the chemical properties of the extractable components in each plant part [5].

3.2. Total Phenol Content (TPC). The total phenolic content varied between the different plant parts of the Passiflora species with respect to the extraction solvent used (petroleum ether, acetone, or methanol). The phenolic content for the extracted leaves and stems ranged from 3.32 to $1.23 \mathrm{~g} \mathrm{GAE} / 100 \mathrm{~g}$ and 3.74 to $1.03 \mathrm{~g} \mathrm{GAE} / 100 \mathrm{~g}$, respectively (Table 1). Among the three solvents, methanol recovered the maximum TPC from the leaves and stems. Petroleum ether was least effective at extracting phenolic compounds. Among the leaf extracts, the methanol extract from $P$. maliformis showed the highest phenolic content $(3.32 \pm$ $0.06 \mathrm{~g} \mathrm{GAE} / 100 \mathrm{~g}$ ), followed by the methanol extract of $P$. edulis at $2.37 \pm 0.11 \mathrm{~g} \mathrm{GAE} / 100 \mathrm{~g}$, whereas petroleum ether and acetone extracts from $P$. quadrangularis produced had lower phenolic contents. In a comparison of the results obtained for the TPC of the P. edulis leaves with those reported in the literature, similar values have been reported for P. alata: $3.42 \pm 0.39 \mathrm{~g} \mathrm{GAE} / 100 \mathrm{~g}$ for ethanol and $1.40 \pm$ $0.49 \mathrm{~g} \mathrm{GAE} / 100 \mathrm{~g}$ for acetone extracts [38]. However, the present TPC values for the leaves of $P$. edulis were higher than those obtained by Silva et al. [39] $(0.83 \pm 0.07 \mathrm{~g} \mathrm{GAE} / 100 \mathrm{~g})$ and four times lower than those reported by Rudnicki et al. [23] (9.25 g GAE/100 g).
The stem extracts of $P$. quadrangularis had the highest TPC value among all of the extracts. Phenolic compounds are widely distributed in plants and have garnered attention due to their antimutagenic, antitumor, and antioxidant properties, which contribute to human health [40]. The variation in TPC values may be attributed to the plant origins of the extractable compounds and the efficacy of the solvents used to recover the polyphenols from the plant materials. Similar variations have been described for Passiflora [23, 41] and for other plants, for example, Pongamia pinnata [5] and Hippophae salicifolia [42]. The variation could also be influenced by geographical origin, cultivar, harvesting, and drying method [43].

3.3. Total Antioxidant Activity (TAA). Significant variation of TAA was observed among the different extracts of the Passiflora species and is presented in Table 1. The present results indicate that the extracts exhibited potential free radical scavenging activity. A lower $\mathrm{EC}_{50}$ value indicates a greater antioxidant activity for a given extract. The TAA ranged from 456.9 to $3423.8 \mu \mathrm{g} / \mathrm{mL}$ and 313.7 to $2137.2 \mu \mathrm{g} / \mathrm{mL}$ for the leaves and stems, respectively. Among the extracts, the strongest TAA was observed in the methanol, followed by the acetone, with the lowest antioxidant activity observed in the petroleum ether extracts. In accordance with the TPC results, the antioxidant activity of the leaf was observed to be highest in the methanol extract of P. maliformis $(456.9 \pm 13.1 \mu \mathrm{g} / \mathrm{mL})$, followed by those of $P$. edulis $(653.5 \pm 6.1 \mu \mathrm{g} / \mathrm{mL})$ and $P$. quadrangularis $(785.2 \pm 1.8 \mu \mathrm{g} / \mathrm{mL})$. The TAA values obtained in this study agreed with the findings of Vasic et al. [38] for the methanol and acetone extracts of P. alata, $808.69 \mu \mathrm{g} / \mathrm{mL}$ and $1107.79 \mu \mathrm{g} / \mathrm{mL}$, respectively. Similarly, the TAA value of the $P$. edulis leaf extract was comparable to that recorded by Sunitha and Devaki [24] $(875 \mu \mathrm{g} / \mathrm{mL})$ using ethanol extracts. The present TAA value for $P$. edulis was higher than that reported previously by Silva et al. [39] $(1100 \mu \mathrm{g} / \mathrm{mL})$ for methanol leaf extract but lower than those reported by Ripa et al. [22] (58.88 $\mu \mathrm{g} / \mathrm{mL}$, using petroleum ether).

The strongest antioxidant activity in the stem was recorded from the methanol extracts for $P$. quadrangularis $(313.7 \pm 1.2 \mu \mathrm{g} / \mathrm{mL})$, followed by those of $P$. edulis $(429.6 \pm$ $3.6 \mu \mathrm{g} / \mathrm{mL})$ and $P$. maliformis $(973.0 \pm 3.7 \mu \mathrm{g} / \mathrm{mL})$. The petroleum ether extract of the $P$. maliformis stem was found to possess the weakest activity $(2137.2 \pm 2.7 \mu \mathrm{g} / \mathrm{mL})$. The TAA values of the stem extracts in the present study were lower than that of the petroleum ether extracts $(54.01 \mu \mathrm{g} / \mathrm{mL})$ of $P$. edulis as reported by Ripa et al. [22]. In general, a higher TPC value led to stronger antioxidant activity. Several authors have mentioned this relationship in previous studies, for example, those of Passiflora species [44] and Veronica species [45]. TPC could be considered as an important indicator of the antioxidant properties of plant extracts. Although TPC has a strong correlation with antioxidant activity, other constituents, such as flavonoids, alkaloids, glycosides, carotenoids, vitamins, and other secondary metabolites, may also be contributing factors [46].

3.4. Antibacterial Activities. The antibacterial activities of the leaves and stems extract of the Passiflora species were tested 


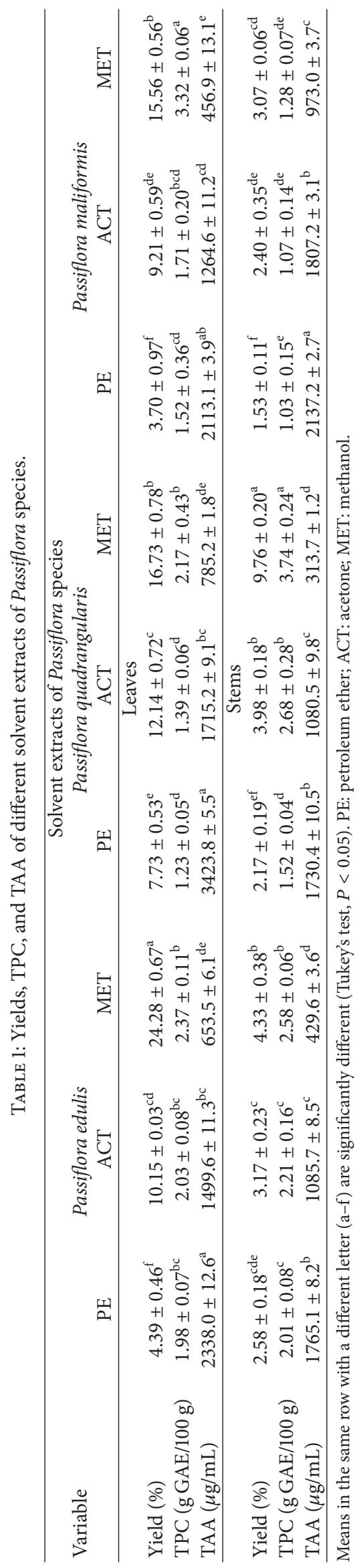




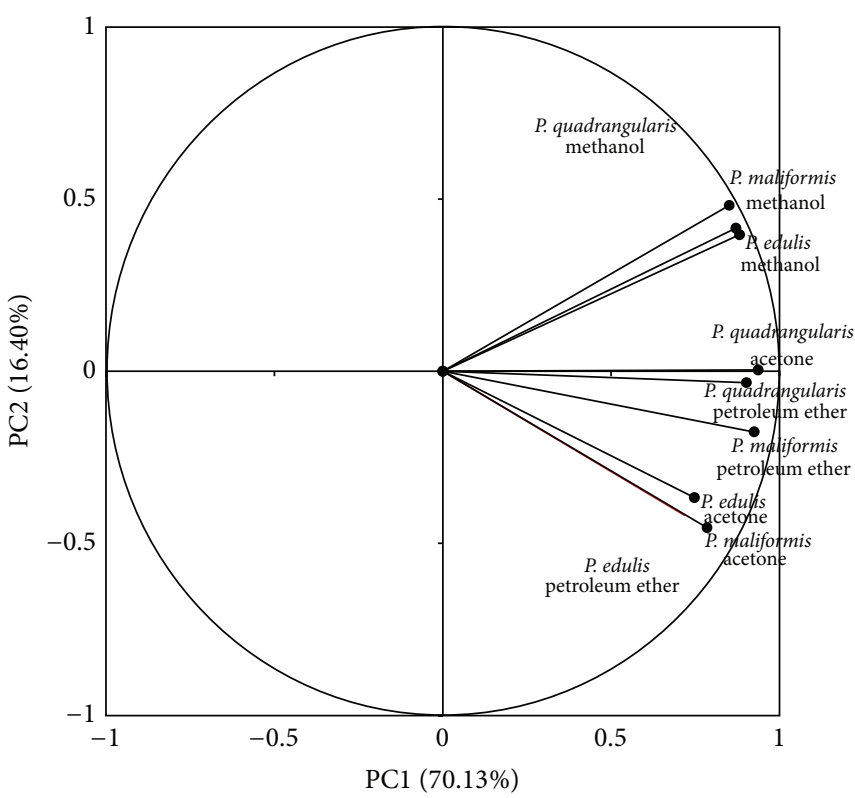

(a) Variables (axes PC1 and PC2: 86.54\%)

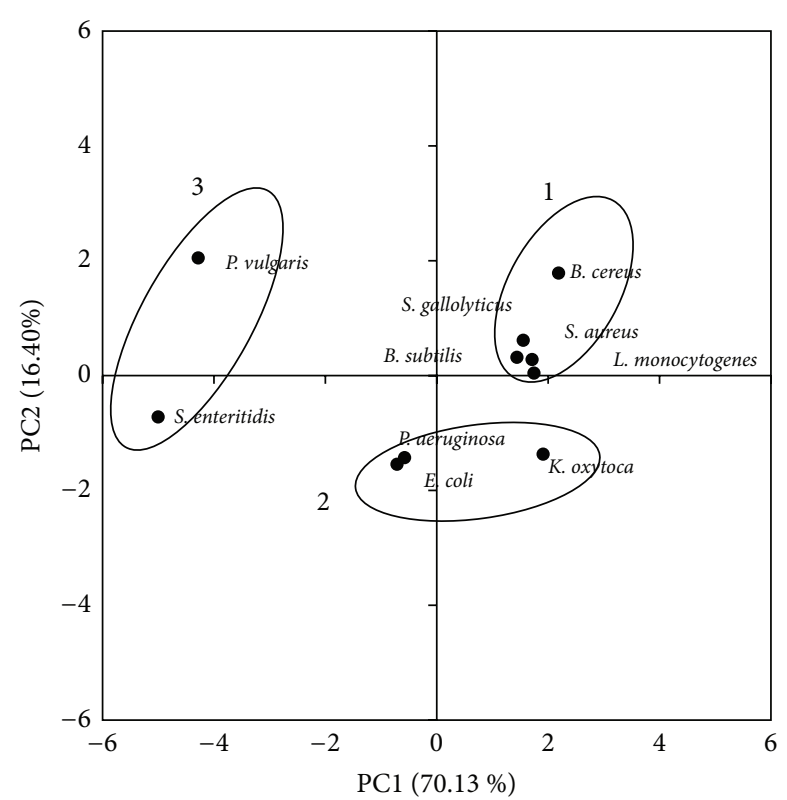

(b) Observations (axes PC1 and PC2: 86.54\%)

FIgURE 1: (a) Plot of the variables tested against pathogenic microbes for leaves extracts. Percentages in parentheses represent the variation of each component. (b) Positions of the PC scores of the 10 microorganisms according to PC1 and PC2.

against 10 human pathogenic bacteria; the results of the tests on the 5 Gram-positive and 5 Gram-negative bacteria are presented in Tables 2 and 3. The observed antibacterial activities were categorized as follows: (a) sensitive-inhibition zone, $>18 \mathrm{~mm}$; (b) intermediate-inhibition zone, $13-17 \mathrm{~mm}$; and (c) resistance-inhibition zone, $<13 \mathrm{~mm}$ [47]. The methanol extracts exhibited considerable antibacterial activity against the bacteria tested. The activity of the methanol extracts might be partly due to their higher phenolic and antioxidant contents. The largest inhibition zone was produced by the methanol leaf extract of $P$. maliformis against $B$. subtilis $(22.5 \pm$ $0.8 \mathrm{~mm}$, sensitive zone). Bacillus cereus and S. gallolyticus were also sensitive to the methanol leaf extract of $P$. maliformis (inhibition zones of $18.7 \pm 0.2 \mathrm{~mm}$ and $20.5 \pm 0.5 \mathrm{~mm}$, resp.). These results showed that the methanol extracts have considerable antibacterial potency despite their crude form.

The potential antibacterial activities of the extracts against the 10 human pathogens are analyzed using PCA and illustrated as biplots in Figures 1 (leaf) and 2 (stem). The PCA indicates that the first two PCs for the leaf extracts accounted for $86.54 \%$ of the total variance. PC1 explained a higher percentage of total variance $(70.13 \%)$ than did PC2 $(16.40 \%)$. For the stem extracts, the first two principal components explained $92.94 \%$ of the total variance, with PC1 and PC2 representing $81.54 \%$ and $11.40 \%$ of the total variance, respectively. The methanol extracts tested were loaded heavily on the positive sites of PC1 and PC2, while the acetone and petroleum ether extracts were connected to the positive sites of PC1 and negative sites of PC2 in both the leaf and stem biplots (Figures 1(a) and 2(a)). The 10 pathogens examined clustered into three main groups in both leaf and stem biplots. For the biplot of the leaf extracts
(Figure 1(b)), the first group consisted of L. monocytogenes, S. gallolyticus, S. aureus, B. subtilis, and B. cereus. This group represents the Gram-positive bacteria, and all the extracts from the three tested solvents showed significant antibacterial activities against this group. The methanol leaf extracts of the Passiflora species exhibited intermediate activity against $S$. aureus $(14.5 \pm 0.6 \mathrm{~mm}), B$. subtilis $(14.0 \pm$ $0.6 \mathrm{~mm})$, and L. monocytogenes $(14.5 \pm 0.5 \mathrm{~mm})$, whereas the petroleum ether and acetone extracts showed smaller zones of inhibition against the other tested pathogenic bacteria. Moderate inhibition was also observed from the methanol and acetone extracts of $P$. quadrangularis against $S$. aureus and B. cereus. Staphylococcus aureus was also moderately susceptible $(14.2 \pm 0.6 \mathrm{~mm})$ to the methanol extract of $P$. maliformis. The acetone and petroleum ether extracts of $P$. maliformis showed intermediate-inhibition zones against $S$. gallolyticus (16.3 \pm 0.3 and $13.5 \pm 0.1 \mathrm{~mm}$, resp.).

The second group was composed of P. aeruginosa, E. coli, and K. oxytoca which are categorized as Gram-negative bacteria and exhibited some degree of sensitivity towards all the extracts.The leaf and stem extracts, as well as the standard, showed weak antibacterial activities towards both $P$. aeruginosa and E. coli. Klebsiella oxytoca was highly sensitive $(21.4 \pm 0.8 \mathrm{~mm})$ to the acetone extracts and moderately susceptible $(\sim 14.0 \mathrm{~mm})$ to the methanol and petroleum ether extracts of $P$. maliformis. The third group consisted of $P$. vulgaris and $S$. enteritidis, and these bacteria were sensitive to the methanol extracts of the Passiflora leaves. Different species exhibited varying degrees of sensitivity to the antibacterial activity of the extracts. These differences can be attributed to the presence of natural antimicrobial compounds in the different parts and species of the Passiflora 


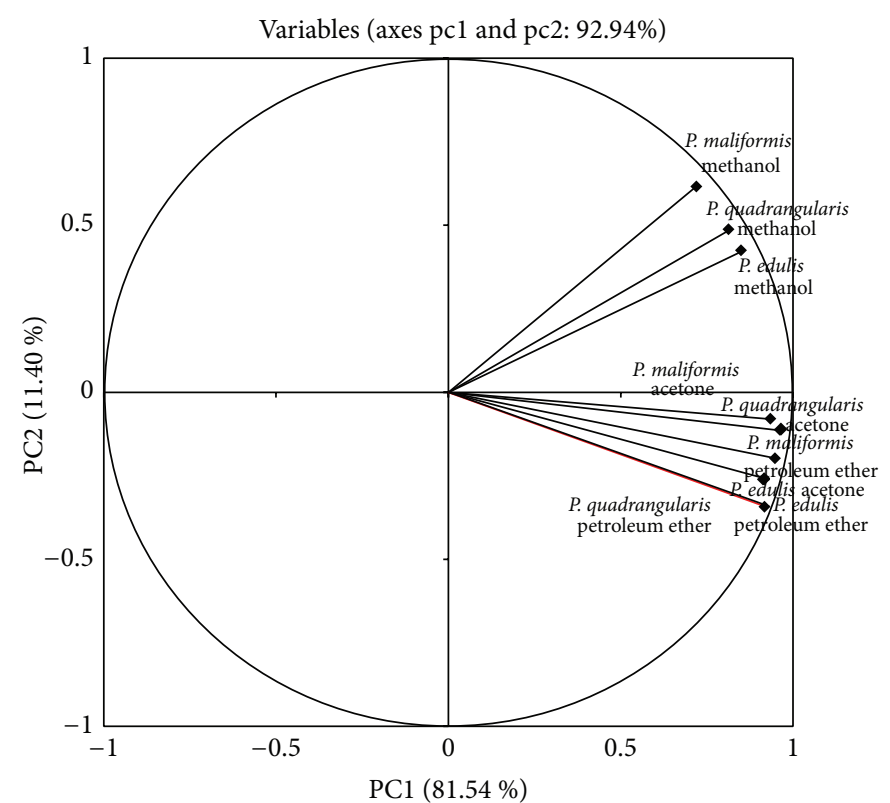

(a) Variables (axes PC1 and PC2: 92.94\%)

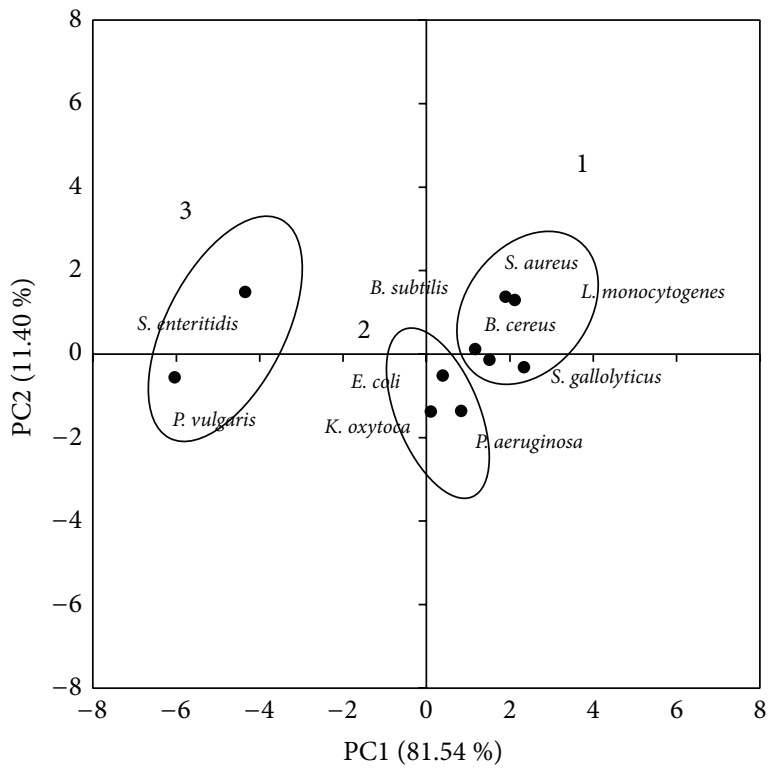

(b) Observations (axes PC1 and PC2: 92.94\%)

Figure 2: (a) Plot of the variables tested against pathogenic microbes for stems extracts. Percentages in parentheses represent the variation of each component. (b) Positions of the PC scores of the 10 microorganisms according to PC1 and PC2.

plants. The antibacterial activity of the P. edulis leaf extract against $S$. aureus in the present study was similar to the levels reported by Akanbi et al. [27] $(12.0 \mathrm{~mm})$ and Kannan et al. [48] $(10 \pm 1.03 \mathrm{~mm})$ for methanol extracts. Johnson et al. [49] reported that chloroform and methanol extracts of the callus tissue and leaves of P. edulis possessed potential antimicrobial activity against $S$. aureus. The antibacterial inhibition against $B$. subtilis in the present results was slightly lower than that obtained $(18.0 \pm 0.88 \mathrm{~mm}$ ) by Kannan et al. [48].

Similarly, for the stem extracts (Figure 2(b)), the first group consisted of the Gram-positive bacteria: L. monocytogenes, S. gallolyticus, S. aureus, B. subtilis, and B. cereus. The methanol and acetone extracts of $P$. maliformis and the methanol extracts of $P$. quadrangularis exhibited intermediate inhibition against S. aureus, S. gallolyticus, and B. subtilis. The second group comprised the Gram-negative bacteria: $P$. aeruginosa, K. oxytoca, and E. coli. The S. enteritidis, which was resistant to only the methanol extracts, and the $P$. vulgaris that was not inhibited by the extracts were clustered in the last group. The obtained values for the antibacterial activities of the stem extracts against $S$. aureus, B. subtilis, $P$. aeruginosa, and $E$. coli were within the range of previous studies of $P$. edulis stem extracts [22, 27]. The PCA showed significant variation between the Gram-positive and Gramnegative bacteria. This result was in agreement with the fact that Gram-negative bacteria possess a unique outer membrane of lipopolysaccharide, which protects them from the permeation of active compounds [50]. The tested extracts showed potential activity against the Gram-positive bacteria; L. monocytogenes, S. gallolyticus, S. aureus, B. subtilis, and B. cereus were all susceptible to the Passiflora extracts, which may be attributed to the presence of a single membrane that makes these bacteria more accessible to the penetration of active plant compounds [51]. This work provides insight into the therapeutic properties of Passiflora in traditional medicine. Further research is required to study the isolates of this plant's bioactive compounds and to evaluate the mechanisms of action for their antioxidant and antibacterial activities.

\section{Conclusions}

The results confirmed the ethnobotanical views of the Passiflora species, which are used in traditional medicine to treat the various infectious diseases caused by the microbes. Methanol was established to be the most effective among the tested solvents at recovering the phenolic and antioxidant contents from the different parts of the Passiflora species. The methanol extract also contained certain constituents with significant antibacterial properties. Gram-negative bacteria were generally less susceptible to the Passiflora extracts than were Gram-positive bacteria. This contrast was illustrated in the biplots generated from the PCA. Although the materials employed in this study are generally considered as plant wastes, they can be used as sources of bioactive constituents. The present study establishes that the leaves and stems of the Passiflora species could be utilized for treating ailments, giving the plants value beyond that of their fruits, which are processed as juice and other products.

\section{Conflict of Interests}

The authors declare that there is no conflict of interests regarding the publication of this paper. 


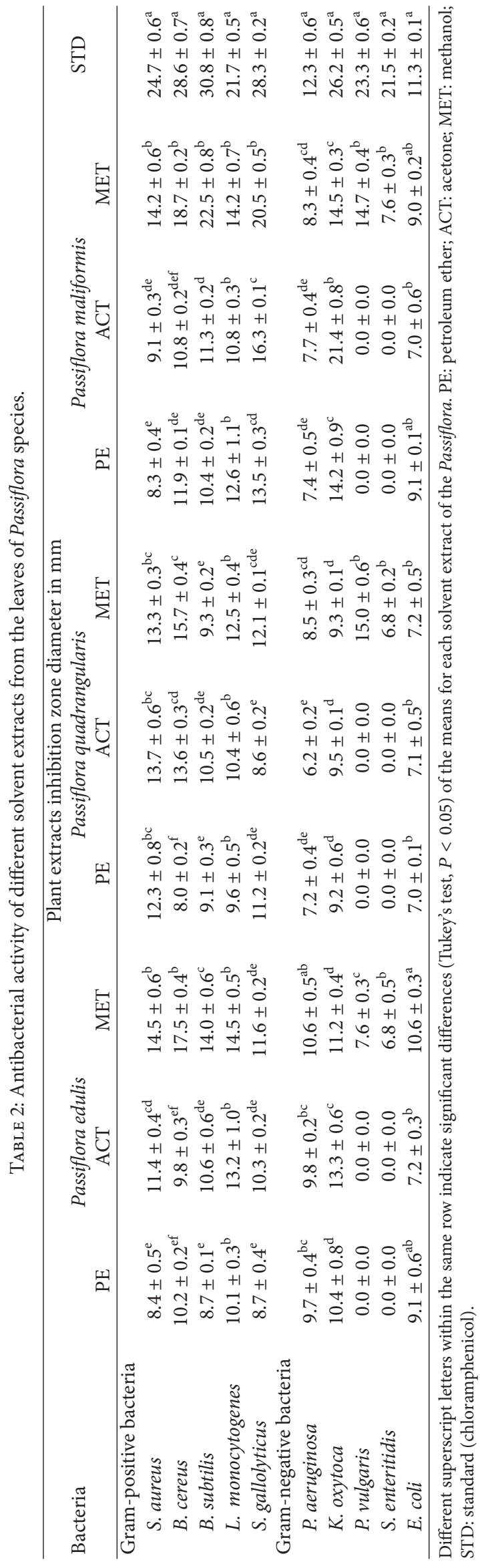




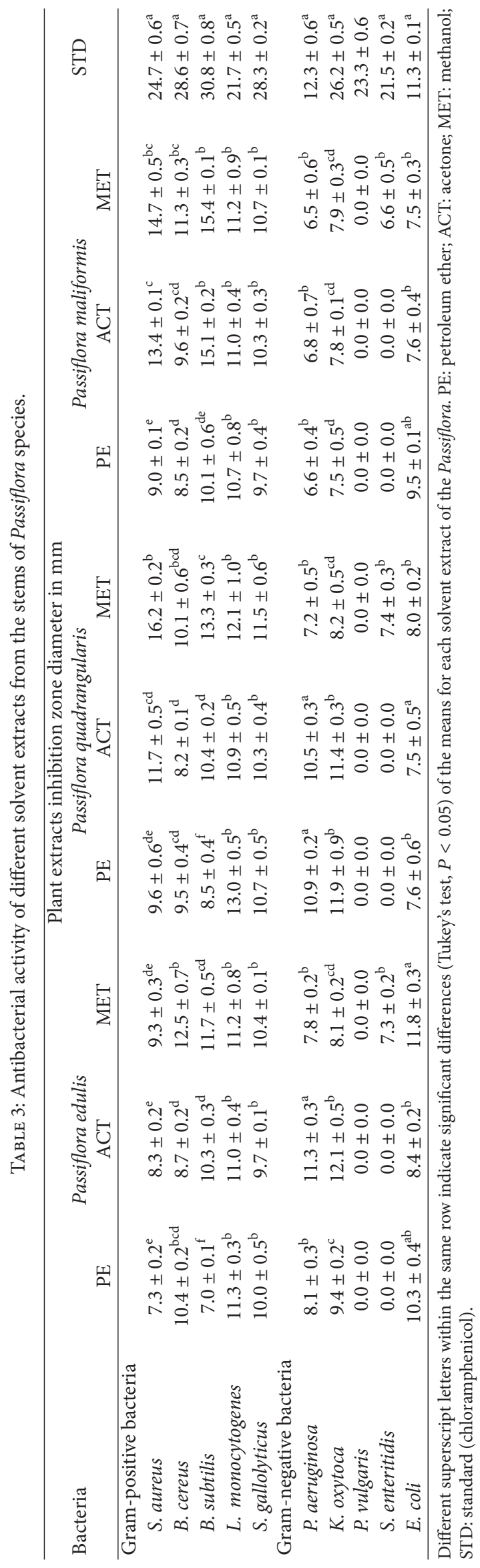




\section{Acknowledgments}

This study was funded by the Ministry of Higher Education Malaysia and UPM under the RUGS-01-01-12-1592RU titled "Comparative studies on passion fruit species and their potential uses." The authors are grateful to the American Journal Expert (AJE) for revising and checking the English language of this paper.

\section{References}

[1] S. Krief, M.-T. Martin, P. Grellier, J. Kasenene, and T. Sévenet, "Novel antimalarial compounds isolated in a survey of selfmedicative behavior of wild chimpanzees in Uganda," Antimicrobial Agents and Chemotherapy, vol. 48, no. 8, pp. 3196-3199, 2004.

[2] S. Tavassoli and Z. E. Djomeh, "Total phenols, antioxidant potential and antimicrobial activity of methanol extract of rosemary (Rosmarinus officinalis L.)," Global Veterinaria, vol. 7, no. 4, pp. 337-341, 2011.

[3] J. Bruneton, Pharmacognosy, Phytochemistry, Medicinal Plants, Lavoisiler, Paris, France, 1995.

[4] J. Davies, "Inactivation of antibiotics and the dissemination of resistance genes," Science, vol. 264, no. 5157, pp. 375-382, 1994.

[5] Z. I. Sajid, F. Anwar, G. Shabir, G. Rasul, K. M. Alkharfy, and A.H. Gilani, "Antioxidant, antimicrobial properties and phenolics of different solvent extracts from bark, leaves and seeds of Pongamia pinnata (L.) pierre," Molecules, vol. 17, no. 4, pp. 39173932, 2012.

[6] T. Ulmer and J. M. MacDougal, Passiflora-Passionflowers of the World, Timber Press, Portland, Ore, USA, 1st edition, 2004.

[7] D. R. Shiamala, S. B. Japar, H. Z. Muta, S. K. Wong, and A. S. S. Muhd, "Sugars, ascorbic acid, total phenolic content and total antioxidant activity in passion fruit (Passiflora) cultivars," Journal of the Science of Food \& Agriculture, vol. 93, pp. 1198-1205, 2013.

[8] S. M. K. Rates, "Plants as source of drugs," Toxicon, vol. 39, no. 5, pp. 603-613, 2001.

[9] M. Bourin, T. Bougerol, B. Guitton, and E. Broutin, "A combination of plant extracts in the treatment of outpatients with adjustment disorder with anxious mood: controlled study versus placebo," Fundamental and Clinical Pharmacology, vol. 11, no. 2, pp. 127-132, 1997.

[10] K. Dhawan, S. Dhawan, and A. Sharma, "Passiflora: a review update," Journal of Ethnopharmacology, vol. 94, no. 1, pp. 1-23, 2004.

[11] S. Akhondzadeh, H. R. Naghavi, M. Vazirian, A. Shayeganpour, H. Rashidi, and M. Khani, "Passionflower in the treatment of generalized anxiety: a pilot double-blind randomized controlled trial with oxazepam," Journal of Clinical Pharmacy \& Therapeutics, vol. 26, no. 5, pp. 363-367, 2001.

[12] K. Dhawan, S. Kumar, and A. Sharma, "Anti-anxiety studies on extracts of Passiflora incarnata Linneaus," Journal of Ethnopharmacology, vol. 78, no. 2-3, pp. 165-170, 2001.

[13] R. K. Gupta, D. Kumar, A. K. Chaudhary, M. Maithani, and R. Singh, "Antidiabetic activity of Passiflora incarnata Linn. in streptozotocin- induced diabetes in mice," Journal of Ethnopharmacology, vol. 139, no. 3, pp. 801-806, 2012.

[14] B. Singh, D. Singh, and R. K. Goel, "Dual protective effect of Passiflora incarnata in epilepsy and associated post-ictal depression," Journal of Ethnopharmacology, vol. 139, no. 1, pp. 273-279, 2012.

[15] R. Soulimani, C. Younos, S. Jarmouni, D. Bousta, R. Misslin, and F. Mortier, "Behavioural effects of Passiflora incarnata L. and its indole alkaloid and flavonoid derivatives and maltol the mouse," Journal of Ethnopharmacology, vol. 57, no. 1, pp. 11-20, 1997.

[16] A. Menghini, M. Capuccella, V. Mercati, L. Mancini, and M. Buratta, "Flavonoid contents in Passiflora spp," Pharmacological Research, vol. 27, no. 1, pp. 13-14, 1993.

[17] C. E. Seaforth, C. D. Adams, and Y. Sylvester, A Guide for the Medicinal Plants of Trinidad \& Tobago, Commonwealth Secreteriate, Marlborough House, London, UK, 1983.

[18] J. Deng, Y. Zhou, M. Bai, H. Li, and L. Li, "Anxiolytic and sedative activities of Passiflora edulis $\mathrm{f}$. flavicarpa," Journal of Ethnopharmacology, vol. 128, no. 1, pp. 148-153, 2010.

[19] H. Li, P. Zhou, Q. Yang et al., "Comparative studies on anxiolytic activities and flavonoid compositions of Passiflora edulis "edulis" and Passiflora edulis "flavicarpa"', Journal of Ethnopharmacology, vol. 133, no. 3, pp. 1085-1090, 2011.

[20] M. K. K. Nippon, "Angiotensin converting enzyme and aldosereductase inhibitory agent-comprises Passiflora quadrangularis extract with organic solvent or water, or vitexin," patent no. 1995-009562, 1993.

[21] A. B. Montanher, S. M. Zucolotto, E. P. Schenkel, and T. S. Fröde, "Evidence of anti-inflammatory effects of Passiflora edulis in an inflammation model," Journal of Ethnopharmacology, vol. 109, no. 2, pp. 281-288, 2007.

[22] F. A. Ripa, M. Haque, L. Nahar, and M. M. Islam, "Antibacterial, cytotoxic and antioxidant activity of Passiflora edulis sims," European Journal of Scientific Research, vol. 31, no. 4, pp. 592598, 2009.

[23] M. Rudnicki, M. R. de Oliveira, T. D. Veiga Pereira, F. H. Reginatto, F. Dal-Pizzol, and J. C. Fonseca Moreira, "Antioxidant and antiglycation properties of Passiflora alata and Passiflora edulis extracts," Food Chemistry, vol. 100, no. 2, pp. 719-724, 2007.

[24] M. Sunitha and K. Devaki, "Antioxidant activity of Passiflora edulis sims leaves," Indian Journal of Pharmaceutical Sciences, vol. 71, no. 3, pp. 310-311, 2009.

[25] L. N. Yuldasheva, E. B. Carvalho, M.-T. J. A. Catanho, and O. V. Krasilnikov, "Cholesterol-dependent hemolytic activity of Passiflora quadrangularis leaves," Brazilian Journal of Medical and Biological Research, vol. 38, no. 7, pp. 1061-1070, 2005.

[26] S. Singh and D. Das, "Passion fruit: a fetched passion fruit for dentists," International Journal of Pharmaceutical Sciences and Research, vol. 4, no. 2, pp. 754-757, 2013.

[27] B. O. Akanbi, O. D. Bodunrin, and S. Olayanju, "Phytochemical screening and antibacterial activity of Passiflora edulis," Researcher, vol. 3, no. 5, pp. 9-12, 2011.

[28] S. Kannan, B. P. Devi, and B. Jayakar, "Antifungal activity of isolated compound from the leaves of Passiflora edulis Sims," Current Pharma Research, vol. 1, no. 1, pp. 35-37, 2010.

[29] J. Birner and J. M. Nicolls, "Passicol, an antibacterial and antifungal agent produced by Passiflora plant species: preparation and physicochemical characteristics," Antimicrobial Agents and Chemotherapy, vol. 3, no. 1, pp. 105-109, 1973.

[30] A. G. Ingale and A. U. Hivrale, "Pharmacological studies of Passiflora sp. and their bioactive compounds," African Journal of Plant Science, vol. 4, no. 10, pp. 417-426, 2010.

[31] S. K. Lam and T. B. Ng, "Passiflin, a novel dimeric antifungal protein from seeds of the passion fruit," Phytomedicine, vol. 16, no. 2-3, pp. 172-180, 2009. 
[32] P. B. Pelegrini, E. F. Noronha, M. A. R. Muniz et al., "An antifungal peptide from passion fruit (Passiflora edulis) seeds with similarities to $2 \mathrm{~S}$ albumin proteins," Biochimica et Biophysica Acta, vol. 1764, no. 6, pp. 1141-1146, 2006.

[33] D. K. Asami, Y.-J. Hong, D. M. Barrett, and A. E. Mitchell, "Comparison of the total phenolic and ascorbic acid content of freeze-dried and air-dried marionberry, strawberry, and corn grown using conventional, organic, and sustainable agricultural practices," Journal of Agricultural and Food Chemistry, vol. 51, no. 5, pp. 1237-1241, 2003.

[34] W. Brand-Williams, M. E. Cuvelier, and C. Berset, "Use of a free radical method to evaluate antioxidant activity," $L W T$-Food Science and Technology, vol. 28, no. 1, pp. 25-30, 1995.

[35] M. K. Lalitha, Manual on Antimicrobial Susceptibility Testing, 2012, http://www.ijmm.org/documents/Antimicrobial.doc.

[36] A. Gahlaut and A. K. Chhillar, "Evaluation of antibacterial potential of plant extracts using resazurin based microtiter dilution assay," International Journal of Pharmacy and Pharmaceutical Sciences, vol. 5, no. 2, pp. 372-376, 2013.

[37] B. Sultana, F. Anwar, and M. Ashraf, "Effect of extraction solvent/technique on the antioxidant activity of selected medicinal plant extracts," Molecules, vol. 14, no. 6, pp. 2167-2180, 2009.

[38] S. M. Vasic, O. D. Stefanovic, B. Z. Licina, I. D. Radojevic, and L. R. Comic, "Biological activities of extracts from cultivated granadilla Passiflora alata," EXCLI Journal, vol. 11, pp. 208-218, 2012.

[39] J. K. Silva, C. B. B. Cazarin, T. C. Colomeu et al., "Antioxidant activity of aqueous extract of passion fruit (Passiflora edulis) leaves: in vitro and in vivo study," Food Research International, vol. 53, no. 2, pp. 882-890, 2013.

[40] Y. Li, C. Guo, J. Yang, J. Wei, J. Xu, and S. Cheng, "Evaluation of antioxidant properties of pomegranate peel extract in comparison with pomegranate pulp extract," Food Chemistry, vol. 96, no. 2, pp. 254-260, 2006.

[41] V. Sasikala, S. Saravanan, and T. Parimelazhagan, "Evaluation of antioxidant potential of different parts of wild plant Passiflora foetida L," Journal of Applied Pharmaceutical Science, vol. 1, no. 4, pp. 89-96, 2011.

[42] M. Saikia and P. J. Handique, "Antioxidant and antibacterial activity of leaf and bark extracts of seabuckthorn (Hippophae salicifolia D. Don) of North East India," International Journal of Life Sciences Biotechnology and Pharma Research, vol. 2, no. 1, pp. 80-90, 2013.

[43] N. Babbar, H. S. Oberoi, D. S. Uppal, and R. T. Patil, “Total phenolic content and antioxidant capacity of extracts obtained from six important fruit residues," Food Research International, vol. 44, no. 1, pp. 391-396, 2011.

[44] S. S. Patel, "Morphology and pharmacology of Passiflora edulis: a review," Journal of Herbal Medicine and Toxicology, vol. 3, no. 1, pp. 1-6, 2009.

[45] U. Ş. Harput, Y. Genç, N. Khan, and I. Saracoglu, "Radical scavenging effects of different Veronica species," Records of Natural Products, vol. 5, no. 2, pp. 100-107, 2011.

[46] J. Javanmardi, C. Stushnoff, E. Locke, and J. M. Vivanco, "Antioxidant activity and total phenolic content of Iranian Ocimum accessions," Food Chemistry, vol. 83, no. 4, pp. 547-550, 2003.

[47] I. O. Okonko, O. B. Donbraye-Emmanuel, A. Ijandipe, A. A. Ogun, A. O. Adedeji, and A. O. Udeze, "Antibiotics sensitivity and resistance patterns of pathogens to nitrofurantoin and nalidixic acid in pregnant women with urinary tract infections in Ibadan, Nigeria," Middle-East Journal of Scientific Research, vol. 4, no. 2, pp. 105-109, 2009.
[48] S. Kannan, B. P. Devi, and B. Jayakar, "Antibacterial evaluation of the methanolic extract of Passiflora edulis," Hygeia-Journal for Drugs and Medicines, vol. 3, no. 1, pp. 46-49, 2011.

[49] M. Johnson, M. Maridass, and V. Irudayaraj, "Preliminary phytochemical and anti-bacterial studies on Passiflora edulis," Ethnobotanical Leaflets, vol. 12, pp. 425-432, 2008.

[50] H. Nikaido, "Microdermatology: cell surface in the interaction of microbes with the external world?" Journal of Bacteriology, vol. 181, no. 1, pp. 4-8, 1999.

[51] H. V. Girish and S. Satish, "Antibacterial activity of important medicinal plants on human pathogenic bacteria: a comparative analysis," World Applied Sciences Journal, vol. 5, no. 3, pp. 267271, 2008. 

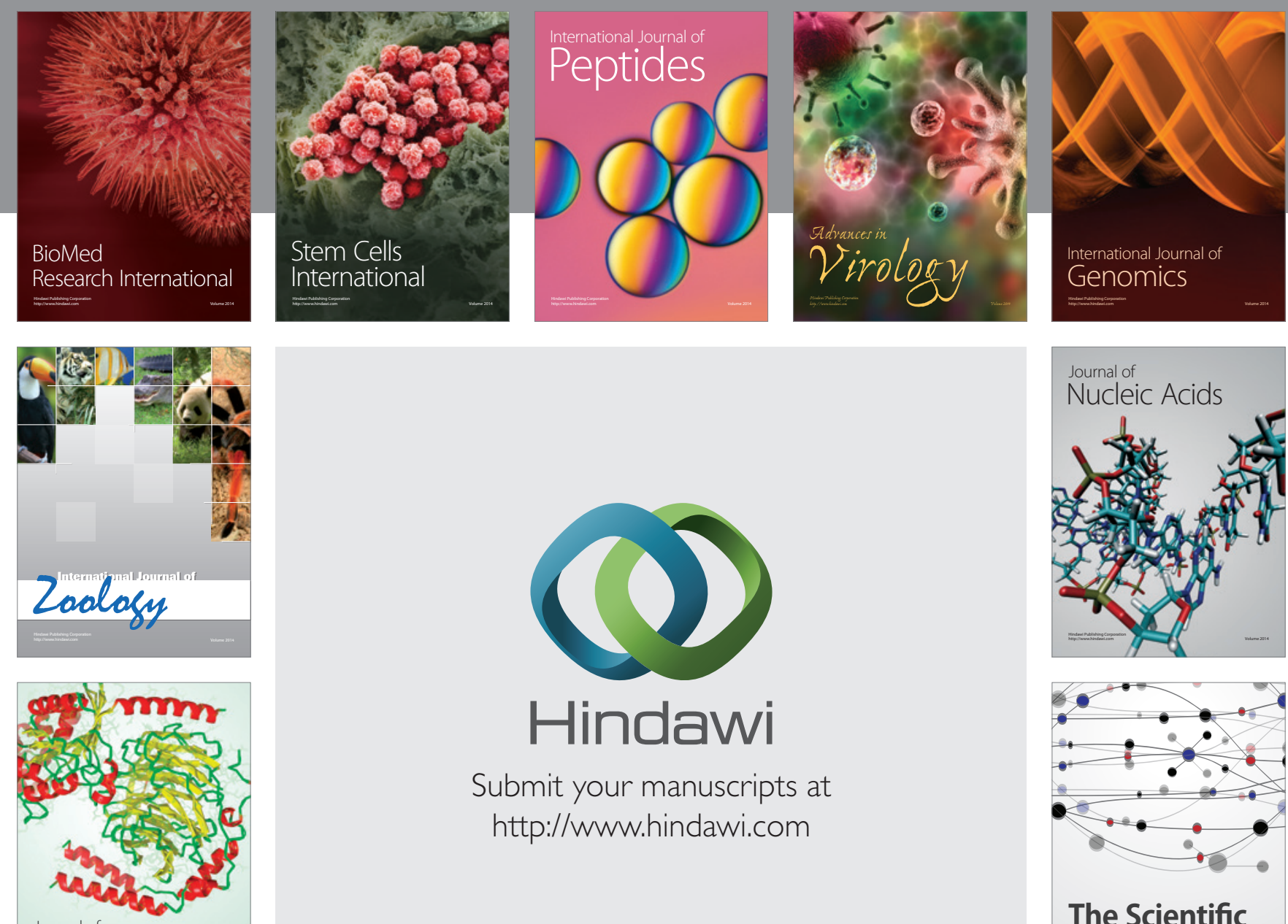

Submit your manuscripts at

http://www.hindawi.com

Journal of
Signal Transduction
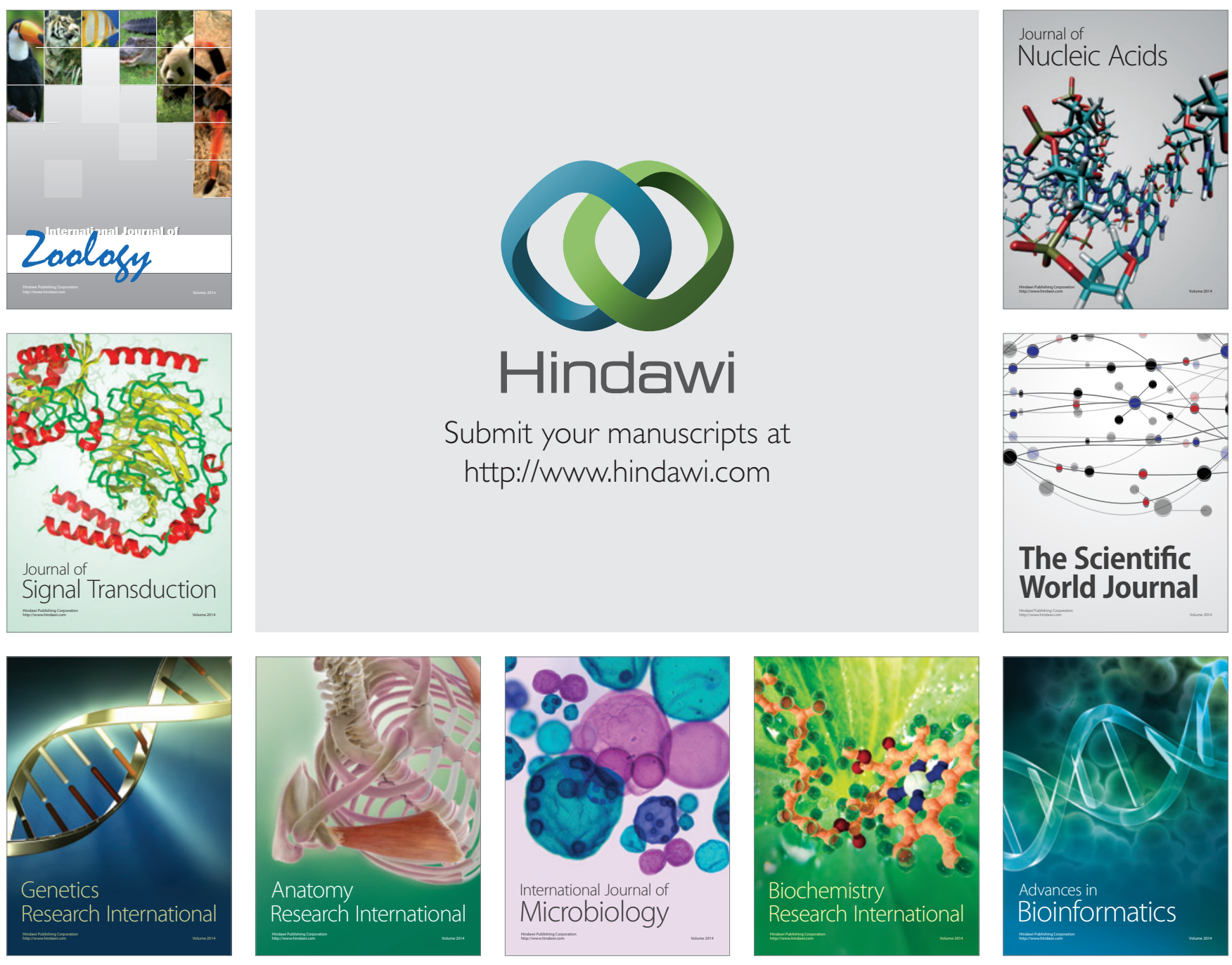

The Scientific World Journal
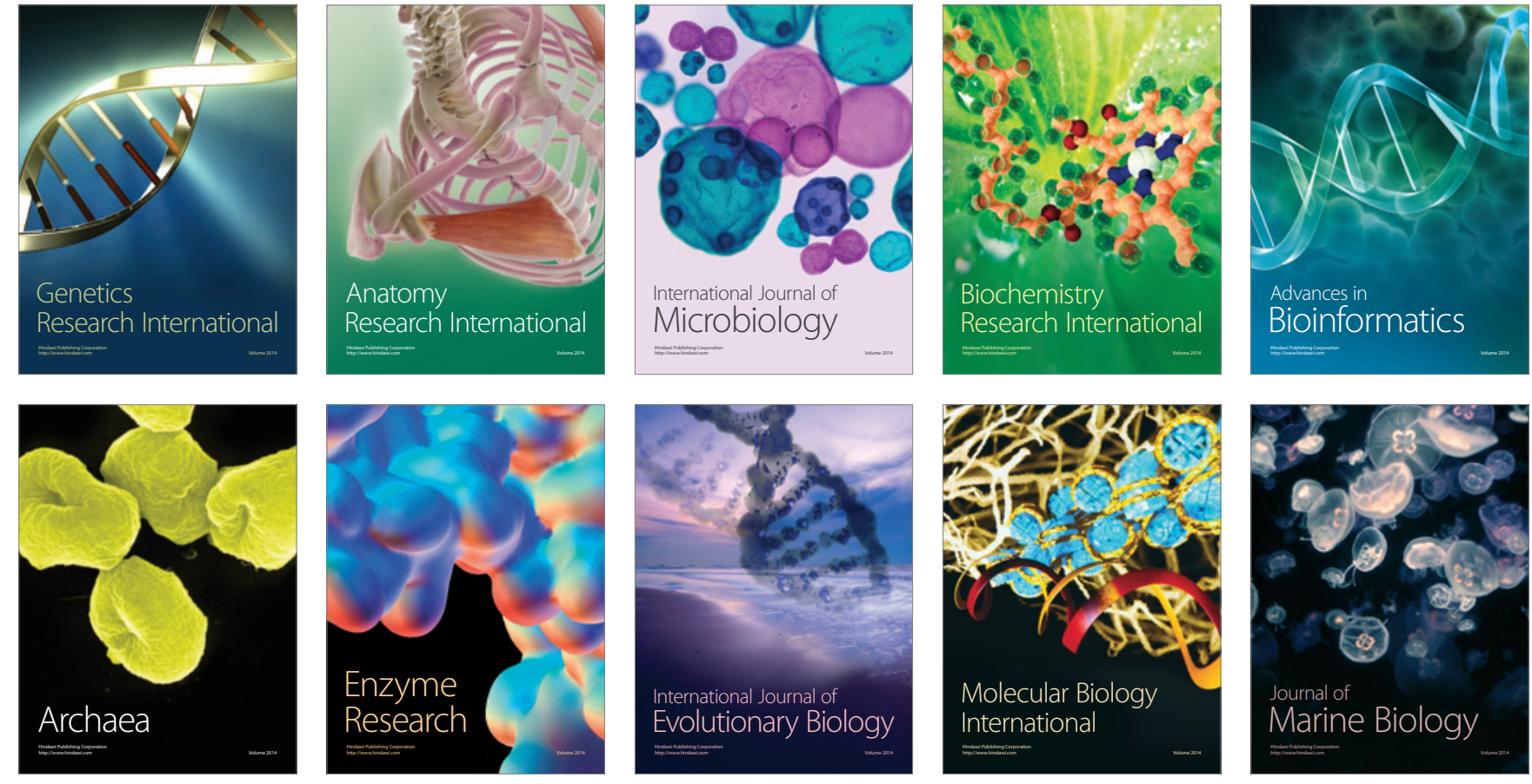